\title{
The Pathogens and Lepidopteran Pests on Corn and Soybeans in the Transylvanian Plain
}

\author{
Loredana SUCIU 1,2, Laura ȘOPTEREAN², Felicia MUREȘANU², Adina IVAȘ², \\ Ana Maria PǍCURAR ${ }^{2}$ \\ ${ }^{1}$ University of Agricultural Sciences and Veterinary Medicine, Faculty of Agriculture, 3-5, Mănăştur, \\ ${ }^{2}$ Agricultural Research \& Development Station Turda, Agriculturiistreet, No.27, 401100, Turda, \\ Romania; suciualexandra1@yahoo.com
}

Bulletin USAMV series Agriculture 71(2)/2014

Print ISSN 1843-5246; Electronic ISSN 1843-5386

DOI 10.15835/buasvmcn-agr: 10889

\begin{abstract}
.
In the climatic conditions in the Transylvanian Plain in corn usually occurs the following diseases and pests: cob rot strains (Gibberella zeae f.c. Fusarium graminearum) common smut (Ustilago maydis) and rust (Puccnia sorghi); Ostrinia nubilalis, Autographa gamma, Agrotis segetum, Agrotis ypsilon, Amathes c-nigrum, Heliothis armigera. In soybeans most common diseases are: bacterial blight (Pseudomonas glycinea), midlew (Peronospora manshurica) and mold (Fusarium spp) and of harmful lepidoptera: Autographa gamma, Agrotis segetum, Agrotis ypsilon, Amathes c-nigrum, Mamestra brassicae and Mamestra suas. In the experimental fields of ARDS Turda in corn crop the most frequent disease was FHB and bacterial blight in soybean and the main pests found were the species Autographa gamma and Agrostis segetum.
\end{abstract}

Keywords: maize, soybean, diseases, pests

Introduction. Maize occupies third place in importance between cultivated plants on earth, for its many uses: animal fodder, getting flour and corn meal, starch and starch derivatives, to obtain oil, industrial alcohol, alcoholic beverages, and soybeans, this "miracle" is the main source of protein for animal feed, vegetable oil for human consumption, raw materials for the food, chemical, pharmaceutical, use soy products for human consumption does not lead to accumulation of uric acid in the human body, responsible for serious diseases such as rheumatism, gout and so on; At the same time, is soybean, the "nitrogen nonpolueted supplier". Both corn and soybeans are host plants for a large number of pathogens and pests that can affect the production of qualitatively and quantitatively. With the Transylvanian plain corn usually occurs following diseases and pests: cob rot strains (Gibberella zeae f.c. Fusarium graminearum) common smut (Ustilago maydis) and rust (Puccnia sorghi); Ostrinia nubilalis, Autographa gamma, Agrotis segetum,
Agrotis ypsilon, Amathes c-nigrum Heliothis armigera. In soybeans most common diseases are bacterial blight (Pseudomonas glycinea), midlew (Peronospora manshurica), white mold (Sclerotinia sclerotiorum) and fusariose (Fusarium spp.) and the most common pests are the harmful lepidoptera Autographa gamma, Agrotis segetum, Agrotis ypsilon, Amathes c-nigrum, Mamestra brassicae and Mamestra suas.

Aims and objectives. The objective of this study was the monitoring of the main pests and diseases present in maize and soybean in the Transylvanian plain.

Materials and Methods. The biological material was represented by corn hybrids and soybean varieties created at ARDS Turda. The degree of infection of various pathogens was determined based on the frequency and intensity on the vegetation period and at harvest. The dynamics on the evolution of the major lepidoptera pests of both crops were determined with synthetic sex pheromone traps, which were 
Tab. 1. Attack degree - FHB 2013

\begin{tabular}{c|c|c|c}
\multicolumn{2}{c|}{\begin{tabular}{c} 
Turda \\
\multicolumn{2}{c}{ Attack gegee \% }
\end{tabular}} & \multicolumn{2}{c}{$\begin{array}{c}\text { Bolduț } \\
\text { Attack degree \% }\end{array}$} \\
\hline Stem & Cob & Stem & Cob \\
\hline 2 & 0.36 & 2.5 & 0.52
\end{tabular}

Tab. 2. Attack degree - Burn bacterial 2013

\begin{tabular}{l|c|c} 
& $\begin{array}{c}\text { Turda } \\
\text { Attack degree \% }\end{array}$ & $\begin{array}{c}\text { Boldut } \\
\text { Attack degree \% }\end{array}$ \\
\hline Observation 1 & $\mathrm{DA}=0.5$ & $\mathrm{DA}=0.7$ \\
\hline Observation 2 & $\mathrm{DA}=0.05$ & $\mathrm{DA}=0.1$ \\
\hline Observation 3 & $\mathrm{DA}=0.04$ & $\mathrm{DA}=0.07$
\end{tabular}

placed at a distance of $30 \mathrm{~m}$ between them, from May to September.

Results and discussion. 2013 is a year characterized by high temperatures recorded, slightly rainy in April, May (the period in which it was planted the corn and soybean) and excessively dry in July. Therefore these climatic conditions and the low inoculum source (properly applied technology for maize and soybean: soil tillage, crop rotation) the manifestation and evolution of diseases in the two cultures was lower than in previous years.

In corn, where the monitorisation was made Fusarium spp. was identified and the attack was assessed, namely the attack to the stem was $2 \%$ and on the cob was $0.52 \%$ (Tab. 1). During the vegetation period Ustilago maydis attack was identified, sporadically.

In soybeans in 2013 , the bacterial burn disese was manifested and as it can be seen in Tab 2, the degree attack of Pseudomonas glycinea pathogen was very low, being below $1 \%$ in all three obervation made.

In corn crop the average number of Autographa gamma adults was 21 and Agrostis segetum adults average was 31. Autographa gamma, present in the corn crop in May, registered a peak in the last decade of the month ( 49 adults), and the second maximum flight was in August in the third decade (44 adults) (Tab. 3). Agrostis segetum adults were present in high number, in culture, in May (63 adults), the second maximum flight was recorded in early August (96 adults) (Tab. 3).

The percentage of insect species recorded in sex pheromone traps in soybean crop was Agrostis segetum 46\%, Autographa gamma 44\% and Amathes c-nigrum 8\% (Fig. 1).

Conclusion. The common diseases in crop fields and experimental plots of corn and soybeans are fusariose and bacterial blight and the main lepidoptera in these cultures are Autographa gamma and Agrostis segetum.
Tab. 3. The abundance (number) of pests present in maize and monitored the period May to September 2013 at SCDA Turda

\begin{tabular}{ccc}
\hline \multirow{2}{*}{$\begin{array}{c}\text { Moniotoring } \\
\text { period }\end{array}$} & \multicolumn{2}{c}{ Pest } \\
\cline { 2 - 3 } & $\begin{array}{c}\text { Autographa } \\
\text { gamma }\end{array}$ & $\begin{array}{c}\text { Agrostis } \\
\text { segetum }\end{array}$ \\
\hline 30 May & 33 & 63 \\
\hline 10 June & 27 & 37 \\
\hline 20 June & 49 & 23 \\
\hline 30 June & 13 & 5 \\
\hline 10 July & 12 & 5 \\
\hline 20 July & 7 & 11 \\
\hline 30 July & 12 & 17 \\
\hline 10 August & 24 & 96 \\
\hline 20 August & 6 & 16 \\
\hline 30 August & 44 & 85 \\
\hline 10 September & 1 & 2 \\
\hline 20 September & 23 & 3 \\
\hline
\end{tabular}

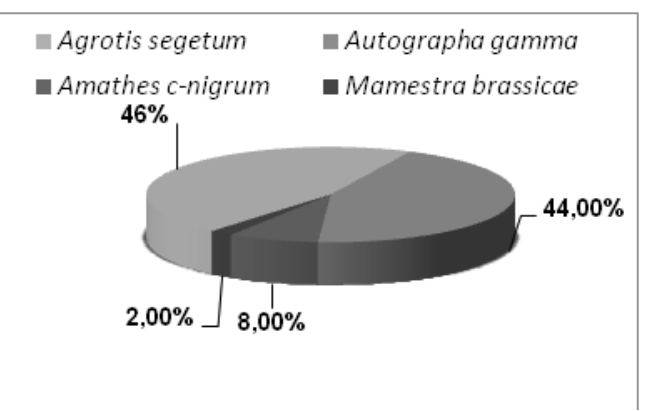

Fig. 1 Percentage repartition of the pests lepidopterist monitored to sex pheromone

\section{REFERENCES}

1. Laura Şopterean, Alexandra Loredana Suciu, Elena Nagy (2012), The behavior of wheat varietes to attack by Fusarium spp. in different test condiţions, at A.R.D.S. Turda 2010-2011, Buletin USAMV, volum 69, pag 302.

2. Mureșanu Felicia, Elena Trotuș, Carmen Lupu, Jinga V. (2013). Diseases and pests in soybean in Romania, The working meeting with theme: SOYBEAN IN ROMANIA - Present and PerspectivesARDS TURDA, 17 to 18 September. 